Leading Article

\title{
The portraiture of Sir William Osler
}

\author{
D.G. James
}

Royal Free Hospital, Pond Street, Hampstead, London NW3 2QG, UK

Harvey Cushing wrote a Pulitzer prize-winning biography of Sir William Osler in 1925, and it was followed by John Fulton's equally brilliant biography of Harvey Cushing. Both biographies vividly encapsulated the contribution of the new Johns Hopkins Hospital to the growth of academic medicine in the United States at the turn of the century, and also beyond, because these biographies have influenced many students worldwide to continue the trial of scientific medicine at its intellectual best.

William Osler held professorships at McGill, Pennsylvania, the Johns Hopkins and finally the Regius Chair of Medicine at Oxford. His textbook The Principles and Practice of Medicine appeared in 1892 and its numerous editions became a world best-seller in the days when authors really were single authors.

Dr Alex Sakula has now provided the world with the perfect reminder of Osler at just the right time, for nowadays postgraduates are too busy to remember him and students have never even heard of Osler. In a delightful preface, Alex Sakula unfolds his own attachments to Osler since 1937 when, as a student, he earned a prize copy of Osler's textbook and went on to become President of the Osler Club of London. He has now immortalized his links with Osler by producing a superb Portraiture, published by the Royal Society of Medicine. ${ }^{1}$ It will be enjoyed with affection and familiarity by Oslerians worldwide; but more important it will introduce the great Sir William to a new generation of heathens, who had never heard of him. All known portraits, mostly from life but some posthumous, in oils or water colour, charcoal sketches, busts, plaques, medallions and medals have been included. Osler had a sallow complexion, drooping moustache, and was balding, so he appeared sombre at first sight, but he was known to have a twinkle in his eye, heart and mind as we know from his alter-ego Egerton Yorrick Davis. It

Correspondence: D.G. James, M.A., M.D., F.R.C.P. Accepted: 16 October 1991 is said that William Harvey had a similar olivegreen complexion.

William Osler (1849-1919) was born in Bond Head, Ontario, Canada, graduated M.D. McGill (1870), elected F.R.C.P. London (1883), F.R.S. (1898) and Baronetcy (1911). He was Regius Professor of Medicine, Oxford (1905-1919) where he lived and died at 13 Norham Gardens. He arrived at Oxford in 1905 determined not only to guide Oxford medicine as its Regius Professor but also to improve the standard of postgraduate education throughout Britain. He argued that without postgraduate education a doctor was stale in 5 years, in the rut by 10 years, and by 20 years so deeply in the rut that he would never be able to get out of it. His influence led to the creation of the Postgraduate Medical Association (1911) and the Fellowship of Medicine and Postgraduate Medical Association (1919) leading to the Fellowship of Postgraduate Medicine. Osler died in 1919 but his influence on postgraduate medicine permeated the 1920s via his friends Henry Wellcome, Sir Humphrey Rolleston, Sir John Bland-Sutton and Sir Thomas Horder. His influence led to the appearance of the Postgraduate Medical Journal in 1925 which was founded to catalyse postgraduate activities and to chronicle the distinguished lectures which were being delivered in various hospitals and at the rooms of the Medical Society of London and the Royal Society of Medicine. ${ }^{2}$ This Journal continues to chronicle those events not only in Britain but throughout Europe. During 1992 the Fellowship of Postgraduate Medicine plans to host a meeting in London to celebrate our medical entry to the Common Market and to welcome European doctors to London.

Sir William Osler would have enjoyed Alex Sakula's vivid portraiture and would have been enthused by the initiative of the Fellowship of Postgraduate Medicine.

\section{References}

1. Sakula, A. The Portraiture of Sir William Osler. Royal Society of Medicine, London, 1991.

2. Hoffbrand, B.I. The Fellowship of Postgraduate Medicine and the Postgraduate Medical Journal. Postgrad Med J 1985, 61: 1-2. 